Case Summaries: International Investment Law

The following summary provides a brief factual background and describes the key findings of a recent case settling a dispute about international investment.

doi:10.1017/S1474745617000179

\title{
Philip Morris Brands Sàrl, Philip Morris Products S.A. and Abal Hermanos S.A. v. Oriental Republic of Uruguay, ICSID Case No. ARB/10/7
}

\author{
Date of Award \\ 8 July 2016 \\ Claimants \\ Philip Morris Brands Sàrl (Swiss Confederation) \\ Philip Morris Products S.A. (Swiss \\ Confederation) \\ Abal Hermanos S.A. (Oriental Republic of \\ Uruguay) \\ Respondent \\ Oriental Republic of Uruguay \\ Treaty

Agreement between the Swiss Confederation
and the Oriental Republic of Uruguay on the
Reciprocal Promotion and Protection of
Investments dated 7 October 1988

\section{Introduction}

On 8 July 2016, an International Centre for Settlement of Investment Disputes (ICSID) tribunal chaired by Professor Piero Bernardini, with co-arbitrators Gary Born (the Claimants' appointee) and Judge James Crawford (the Respondent's appointee), issued its award in Philip Morris Brands Sàrl, Philip Morris Products S.A. and Abal Hermanos S.A. v. Oriental Republic of Uruguay (Award). The Award dismissed all of the Claimants' claims and ordered the Claimants to pay $70 \%$ of Uruguay's legal costs and expenses.

The Claimants-tobacco manufacturers, exporters, and distributors in the Uruguayan market - filed a claim at ICSID in 2010 requesting compensation in respect of two tobacco control measures enacted by the Uruguayan government (Challenged Measures) as follows:

- On 18 August 2008, the Ministry of Health enacted the Single Presentation Regulation (SPR), which: (i) permitted only a single presentation of each cigarette 
brand (e.g., Marlboro Red only and not Marlboro, Marlboro Gold, Marlboro Blue, and Marlboro Fresh Mint), thereby precluding the Claimants from marketing more than one variant of each family brand; ${ }^{1}$ and (ii) required pictograms consisting of five images and five statements to appear on $50 \%$ of the packet display area.

- On 15 June 2009, the President of Uruguay enacted the 80/80 Regulation imposing an increase from $50 \%$ to $80 \%$ in the size of health warnings on the front and back surfaces of cigarette packets, leaving just $20 \%$ of this space available for identifying trademarks and logos.

The Claimants alleged that the Challenged Measures infringed their intellectual property rights and diminished the value of their investment in Uruguay in breach of investment protections under the Switzerland-Uruguay BIT. The Claimants sought an award of damages or, alternatively, removal of, or immunity from, the Challenged Measures.

A majority of the Tribunal rejected all of the Claimants' claims. The Claimants' party-appointed arbitrator issued a partial dissent in relation to the majority's findings that the SPR did not breach the fair and equitable treatment clause, and that there was no denial of justice.

\section{Why Is This Case Relevant?}

The Award endorses the power of States to regulate to protect public health and confirms that-provided regulatory measures are based on rational grounds and made in good faith - they will not give rise to an expropriation or a breach of the fair and equitable treatment protection.

The case is also of interest because the Tribunal analyzed the content of the rights accorded by a trademark by reference to several international treaties, including the Agreement on Trade-Related Aspects of Intellectual Property Rights (TRIPS Agreement).

\section{Main Findings of the Arbitral Tribunal ${ }^{2}$}

\section{Trademarks Do Not Accord the Holder an Absolute Right of Use, but Rather a Right to Exclude Use by Others}

The Tribunal began by analyzing what rights are comprised in a registered trademark namely, a right to use the trademark without being impacted by future regulations or an exclusive right to exclude third parties from using the trademark. The parties agreed that Uruguay's Trademark Law was based on a number of intellectual property conventions, including the TRIPS Agreement. The Claimants relied on various sources,

1 For example, for the Malboro family, Philip Morris chose Malboro Red, leading to the removal of Malboro Gold, Blue, and Fresh Mint from the market.

2 Claims related to impairment of use and enjoyment of the investment under Article 3(1) of the BIT and failure to observe commitments as to the use of the trademark under Article 11 of the BIT are not discussed given their lesser significance to the Award. For information regarding these claims, see Award, paras. 444446 (impairment of use and enjoyment), paras.457-458, 467-482 (failure to observe commitments). 
including Article 20 of the TRIPS Agreement, in asserting that a trademark holder has an implied 'right to use' a trademark, the effect of which is to preclude a WTO Member State from unjustifiably imposing special requirements on trademarks used in the course of trade. The Respondent contended that, under Uruguayan law, a trademark conferred only a right to protect against use by others.

After assuming the Claimants' ownership of the trademarks at issue, ${ }^{3}$ the Tribunal determined the rights accorded by a trademark in light of the provisions of the 1883 Paris Convention for the Protection of Industrial Property, the TRIPS Agreement, and the Mercosur Agreement. The Tribunal found that a trademark holder does not enjoy an absolute right of use, free from regulation; instead, it holds an exclusive right to prevent third parties from using the trademark. The Tribunal's finding relied in part on Article 15 of the TRIPS Agreement regarding 'Rights Conferred', which it decided did not incorporate a right to use, but rather only an exclusive right to prevent third parties from using the trademark.

\section{The Challenged Measures Did Not Give Rise to an Indirect Expropriation of the Claimants' Investment}

The Tribunal, having determined that trademarks are property rights capable of expropriation, went on to find that the Challenged Measures did not give rise to an indirect expropriation. Rather, the Tribunal concluded that they reflected a valid exercise by Uruguay of its police powers for the protection of public health, and that they had been adopted in good faith and in a proportionate and non-discriminatory fashion.

In particular, the Tribunal found that:

- The 80/80 Regulation did not bring about an expropriation as: (i) the Claimants' logo could still appear on $20 \%$ of the surface area of a cigarette packet; and (ii) the increase from $50 \%$ to $80 \%$ of regulated content on the packet did not substantially impact the business as a whole.

- In order to determine the expropriatory character of the SPR, the impact on the Claimants' Uruguayan business as whole had to be considered - rather than the impact on each individual brand asset - since the measure affected its activities in their entirety. Because sufficient value remained in this business, even following the implementation of the SPR, the measure was not expropriatory.

Uruguay Did Not Breach the Fair and Equitable Treatment Standard as the Challenged Measures Were Not Arbitrary and Did Not Breach Claimants' Legitimate Expectations

A majority of the Tribunal found that the Challenged Measures did not meet the international law test for arbitrariness, which requires a wilful disregard of due process of law or an act that shocks - or at least surprises - a sense of judicial propriety. In particular, the Challenged Measures were not arbitrary as they: (i) were implemented to

\footnotetext{
3 The parties disagreed about Claimants' ownership of the trademarks; finding that it could not reach a decision on this issue, the Tribunal proceeded on the assumption that Claimants owned the trademarks.
} 
protect public health; (ii) enacted in good faith; (iii) were adopted with appropriate scientific support on the basis of the Framework Convention on Tobacco Control (FCTC) to which Uruguay was a party, and related guidelines (Uruguay was not required to perform its own independent scientific studies); and (iv) impacted the Claimants' Uruguayan business in a minor way.

The Claimants' appointee dissented, concluding that the fair and equitable treatment protection had been violated because the SPR was arbitrary and disproportionate on grounds that: (i) its content was not appropriate to prevent misleading, false, or deceptive use of trademarks; (ii) the FCTC did not recommend adoption of the SPR; and (iii) the Respondent produced very limited documentation regarding the introduction of the SPR Regulation and those documents actually produced showed that it was adopted hastily without serious study or debate.

The Tribunal further concluded that the measures did not breach the Claimants' legitimate expectation to exploit its brand assets and enjoy its intellectual property rights as: (i) the Claimants received no relevant undertakings in relation to those investments at the time of investing or afterwards; and (ii) the Claimants had a profitable business in Uruguay even after implementation of the Challenged Measures.

\section{The Claimants Were Not Denied Justice, but Rather Enjoyed Due Process and Fair Treatment By the Uruguayan Courts}

The Tribunal rejected the Claimants' allegations that two events gave rise to a denial of justice.

First, the issuance by the Supreme Court of Justice (SCJ) and the Tribunal de lo Contencioso Administrativo (TCA) (an administrative court) of two allegedly contradictory decisions regarding the Executive Branch's power to increase from $50 \%$ to $80 \%$ the size of warnings on cigarette packets. In a constitutional challenge to the 80/80 Regulation, the SCJ concluded that it was constitutional because it did not grant the Ministry of Public Health the power to require health warnings covering more than $50 \%$ of the surface of cigarette packets. The TCA, on the other hand, in administrative proceedings regarding the same regulation, found that the 80/80 Regulation was permissible precisely because previous Uruguayan laws allowed the Ministry of Public Health to require warnings covering more than $50 \%$ of cigarette packets.

A majority of the Tribunal acknowledged the unusual position - a 'quirk of the judicial system' - that there were alternative mechanisms for constitutional and administrative review, but no judicial avenue to reconcile contradictory decisions. However, it concluded that the discrepancy did not amount to a denial of justice, as the Claimants had enjoyed their day in court and received a properly reasoned decision. The Claimants' party-appointed arbitrator dissented and considered that a denial of justice had arisen because the contradiction between the SCJ's and TCA's decisions was serious, and in light of the absence of a means of recourse to square the contradictory decisions.

Second, the TCA - in rejecting the Claimants' challenge to the SPR - relied on evidence and arguments advanced by a competitor, British American Tobacco, in a 
separate case. ${ }^{4}$ The Claimants alleged that the TCA's failure to take account of their arguments amounted to a breach of the fundamental principle of procedural fairness. The Tribunal rejected the Claimants' allegation, finding that - although 'regrettable' the TCA's references to BAT's submissions were not dispositive of the Claimants' case and did not undermine the propriety of the process in a way that amounted to a denial of justice. illegal. 